\title{
特集記事
}

\section{「ディジタルコンテンツ：画像・映像」 特集号の企画にあたつて*}

\author{
相良 直哉**, 桑原 明栄子 $* * *$
}

\section{Digital Image Contents}

\author{
Naoya Sagara and Meeko Kuwahara
}

ディジタル画像処理はその発展とともに, 多岐に渡っ て静止画像だけでなく動画像を記録と分析の手段として 活用されるようになりました。 また，ディジタルカメラ の普及により，個人においても画像を記録する機会も増 加しております。その画像情報を活用するための研究が 進められており，いろいろなアプリケーションソフトも 開発されています。そこで, 本特集では, ディジタルコ ンテンツ：画像・映像という広範囲にわたる分野から画 像・映像コンテンツを活用するための研究を紹介するこ とにいたしました.

「見ること, 分かること, 魅せること」では, 可視化 処理の表現結果において, 人の理解を助けることを「魅 せる」ことと考えて場合，見ること，分かることとはど のようなことかを解説していただくとともに，「魅せる」 ための表現方法について，「区別を容易に」「魅せる部分 の限定」,「3 次元形状の誇張」,「動きの誇張に」の 4 つ に分けて詳しく解説していただきました.

「画像情報の再構成による人間行動の可視化」では, 画像情報を人間自身で視認するための可視化技術の動向 とともに，並び替えられた静止画や動画から高水準な情 報を抽出する処理によって, 再構成された画像情報を可 視化する各種技術について解説していただきました。ま た, 画像情報の可視化が従来の可視化技術と概念的にど のように異なるのかを抽象化して議論することで, 今後 の可視化研究の方向性を解説していただきました。

「曖昧な情報要求からの探索を支援するリング状検索 インタフェース一植物検索とアプリ検索への適用による 効果一」では, 画像検索において, 検索する画像のイ メージは持っているが，検索のキーワードがわからない 状態など, 曖昧な情報要求においても, 柔軟に画像検索 できるリング状検索インタフェースについて紹介してい

* 原稿受付 2015 年 11 月 3 日

** 非会員一橋大学 経済研究所 （１86-8603 東京都国立市中 2-1，

E-mail : sagara@ier.hit-u.ac.jp)

*** 非会員 明星大学 情報学部

（１91-8506 東京都日野市程久保 2-1-1,

E-mail : meeko.kuwahara@meisei-u.ac.jp)
ただきました．また，植物検索とアプリケーション検索 への適用とその効果についても詳しく解説していただき ました。

「電磁流体のビジュアルシミュレーションー CG 表現 のためのモデリングと可視化一」では, 電磁流体力学の 基礎方程式で記述される太陽表面の活動とオーロラの 2 つの自然現象と, 磁性流体の物理現象の CG 表現の手法 について紹介していただきました，主に視覚的な効果を 重要視した CG としてのアプローチを採用することで, 電磁流体の振る舞いによって生じる現象を CG で再現で きていることを解説していただきました.

「コミュニケーションにおける課題解決のための可視 化一編集と翻訳による価值の定義とストーリーテリング 一」では, コミュニケーションにおける課題解決のため の可視化手法について,「震災後の自動車通行実績マッ プ」,「フェンシング・ビジュアライズド」「Social Ticker」という3つの事例をもとにその重要性を解説 していただきました。また，カンヌライオンズ・クリ エーティブデータ部門の受賞作の中から，優れた表現に よるストーリーテリングのための可視化について紹介し ていただきました。

「オノマトペの可視化一模様による天候のオノマトペ の可視化に関する調査一」では, 日本語のオノマトペの 印象を体系化し，それらが持つイメージを模様として可 視化した場合における共通認識についての調査, 考察さ れ，日本語話者のオノマトペの使用の摇らぎなどについ ても報告していただきました.

今回の特集では, ディジタルコンテンツ：画像・映像 というテーマで, 画像情報を活用するための研究を紹介 いたしました。画像の活用方法にご興味をいただき，い ろいろな分野においても画像を活用していくことの助け となれば幸いです，最後に，今回の特集記事のご執筆を ご快諾いただきました執筆者各位, 関係者の皆さまに深 く感謝を申し上げます。 